\title{
Housing Accessibility Constraints amongst Public Servants in Ogun State Nigeria - A Case of Ota, Ogun State.
}

\author{
Orekan, Atinuke Adebimpe \\ Department Of Estate Management, College of Environmental Sciences, Bells University Of \\ Technology, Ota, Ogun State, Nigeria. \\ *Corresponding author: tinuorekan@ymail.com
}

\begin{abstract}
This study examined the constraints in housing ownership amongst public servants in Ota, Ogun State. The work specifically sought to find the factors that could affect housing accessibility among target population in the study area. In achieving the aim of the study, survey was conducted among the selected population which was later confirmed with interviews. The causative factors of housing constraints were tested with the use of one-way ANOVA to test the significant difference in the response of the respondents and POST- HOC was used in the ranking of these factors. It was revealed that finance and institutional impediments are the two major factors amongst others that affect housing accessibility in the study area among public workers. Narrative and descriptive research designs in form of tables, bar charts and theoretical analysis were adopted. The study thus recommends that mortgage institutions and finance houses to have a special consideration and arrangement to public servants and low-income earners so as to increase of descent residential properties in major cities in Nigeria.
\end{abstract}

Keywords: Public servants, Housing Constraints, Property development, Ota

\subsection{INTRODUCTION}

Provision of affordable houses has been a major task facing Nigeria government despite the fact that it is part of their agenda at the beginning of their tenure. The availability of housing stock could determine the wealth base of any nation. Nubi (2010) opined that housing market contributes a significant proportion of the Gross Development Product (GDP). He further showed that residential mortgages alone contribute over $87 \%$ of the GDP in Denmark and $71 \%$ in the USA. However, in the UK it is slightly lower at $70 \%$ of the GDP while in Germany residential mortgages contribute $54 \%$ of its GDP. In addition, Hong Kong stands at $31 \%$ and Nigeria contributes comparatively lower at $0.8 \%$. This implies that the effort of Nigerian government in improving housing stock has not progress with regards to the provision of affordable houses.

The source and the availability of funds have a significant effect on property development and its operation. The complexity involved in housing development and its capital intensive nature demands proper and adequate funding to make it realisable. It is noted that property development is a crucial aspect that will pose a positive impact on the economy of a nation as the case may be in Nigeria. Available finance to individuals will boost and smoothen out consumption and reduce poverty and accessibility to finance will improve the economic growth of any nation.

A city like Ota is an economically developing town that has one of the largest concentrations of industries; particularly the manufacturing and assembly plants. It also has tertiary institutions. In 
spite of the status of the city, Ota has only one housing estate built by the government. Most of the property developments have been on individual basis. With the nature and standard of buildings around Ota, it is obvious that most of the property owners do not have sufficient finance or credit facilities to develop properties and they can be referred to as the urban poor. The urban poor constitute between $33 \%$ and $67 \%$ of the urban population in less development countries (LDCs) such as Nigeria (Lewin, 1981, Olotuah, 2000). The common source of fund for property investment for public servants is through personal savings and lending. In the corporate organisation, they provide accommodation for their employees through staff quarters and also make available housing loan for their staff. Various studies of financing real estate development have been conducted by several researchers in different countries which have examined problems faced in the accessibility of real estate. It was revealed by Nubi, (2010) that little success is recorded for mortgage system despite several efforts to develop it. On the other hand, Nubi and Ajoku (2011) have recognised the fact that accessibility to land has a great impact on housing delivery. Other notable factors are institutional impediments, family size, building materials, construction, etc.

This study seeks to identify the variables that have more effect on housing constraints amongst public servant in the study area through the use of the Multiple Regression Model. It enables one to predict the value of a variable based on the value of two or more variables. It is hoped that this paper will contribute to ways of providing housing to public servants and assist in improving quantity of houses in the study area.

\subsection{LITERATURE REVIEW}

\subsection{Housing provision and source of finance in Nigeria}

Shelter has been universally accepted as the second most important essential human need after food. Housing in its entire ramification is more than mere shelter since it embraces all forms of social services and utilities that go to make a community or neighbourhood liveable environment (National Housing Policy, 1991). Generally, one without a house or shelter is not recognised in the society and the more cash one acquired, the more shelter one is likely to provide most especially in the city.

The federal government of Nigeria has made efforts through the National Housing Scheme programme to provide shelters. However, not much was achieved through this scheme to provide accommodation to people and the state government also could not achieve to provide the same through the state housing co-operation. Despite all these efforts the problems of accommodation have not resolved. Ubom (2014) has highlighted that 72 million Nigerians out of a total inhabitant of 165 million Nigerians are homeless. This implies that only $66 \%$ of the country's total population have one form of a house or the other. From this, it can be implied that housing is a major challenge that the government is facing despite all its effort.

Our major cities in Nigeria like Lagos, Port Harcout, Abuja etc have a more pronounced challenge facing them in terms of housing. The population and infrastructure in these areas are high and there are limited accommodations for people. In order to mitigate the housing problems, mortgage financial institutions were often approached. The housing handbook of 1991 defines mortgage as an instrument recognised by law through which property is given up as security without necessarily giving up possession of it for repayment of a debt or obligation. Some of the roles of Primary Mortgage Institutions include a) granting of loans to any person for the building, improvement or extension of a dwelling/commercial house; b) granting loans and advances to any person for the purchase of a dwelling/commercial house; c) acceptance of savings and deposits from the public and payment of interest thereon; d) performing estate management duties;e) offering of project consultancy services for estate development (Chris and Owar, 2017)

Primary Mortgage Institution was established by the federal government to assist in providing housing for people. According to Alebiosu (2009), housing is one of the basic needs of man next to 
food. In this respect, housing has been a problem faced by lots of people. They find it difficult to have access to decent and affordable accommodation in cities. Ubom (2014) discussed several factors comprising poverty level in the country, cost of constructing a good building, poor savings, highly changing macroeconomic policies, processes in land acquisition and the complex structure of the mortgage financing in Nigeria to be the factors that contribute to this difficulty.

\subsection{Housing Constraints in Nigeria}

As Nigeria has a population of about 170 million according to the last count of the population census of 2006, the tendency for housing supply to meet the demand is slim. According to Udoka and Owor (2017), they supported this notion by stating that the demand for housing overweighs the supply for housing despite all efforts made by both government and the private sector to provide affordable shelter.

The available houses are not affordable by the low-income earners and there are no flexible established alternative routes to source for finance in the provision of housing especially by the lowincome earners. According to Olotuah (2006), the problems of inadequate provision of housing in Nigeria stems from the inability of the National Housing Fund (NHF) to fund housing developments. This implies that if the NHF have all the necessary machineries to perform effectively, the availability of fund to the public for housing finance will be improved. To further support this claim, Omirin (2007) revealed that existing realities which indicates that the potential of mortgage industries remain untapped as it is constrained by factors undermining the access and sustainability of mortgage finance by the average poor citizen in Nigeria. The Primary Mortgage Institutions that are expected to grant loans to the public are not meeting this obligation.

Warnock (2008) investigated the effects of housing market in the provision of housing finance in twelve different countries which include Malaysia, China, and Indonesia. It was concluded that efficient legal system, stable and conducive macroeconomics environment, existence of credit information systems had positive effects on mortgage finance system. From these several studies, the provision of housing finance in these countries has been well structured and regulated which has improved housing provision for every citizen. In the case of Nigeria, the case seems different. A well- structured policy, legal system and the information system that will improve the housing finance especially amongst the low-income earners requires attention by the government to aid housing finance. Iyaiya (2012) collaborated this based on the research he carried out on the microfinance and mortgage financing in Nigeria. The research revealed that the establishment of a regulatory body would ensure the construction of decent houses with the risk of land purchase eliminated and tenure security ensured.

\subsection{Challenges in Real Estate Investment}

Ownership of a house is linked to the acquisition of land. Land acquisition in the urban area amongst people including public servants is prone to a lot of challenges despite the Land Use Act which was enacted to make land accessible to the people. One would expect that with the Act in place it will assist the accessibility to land and will have a positive effect on housing delivery.

The bureaucratic process in getting the Certificate of Occupancy is an aspect to be reformed. Some administrative aspect of the Act have hindered the good intention of obtaining a certificate of occupancy, subdivision of titling, grant of consent to assign and land acquisition. These have adverse effect on housing. Ownership of houses involving land acquisition in the urban area is prone to a lot of challenges. Despite the Land Use Act which was enacted to make land accessible to people, it is still a great challenge. One would expect that with the Land Use decree in place, it will assist house ownership. Aluko, (2012) had reacted to the Act by stating that like most other land policy enactments and land reform legislations, the Land Use Act is intended to achieve a number of political, economic and social objectives. Unfortunately, this has not gone far in the area of housing for people. Similarly the cost of building materials is high in Nigeria compared to some of the countries in Africa. A bag of 
cement sells for N1, 800 in Nigeria while it sells for an average of N800 in most of North African countries. The cost of building materials is a key factor that has led to high cost of construction in Nigeria. Abiodun (1985) reported that the restriction on the importation of cement which by account constitutes about $40 \%$ of building materials has led to the sharp increase of the cement. Nigeria does not produce enough cement domestically to meet demand; imports have been restricted and subjected to a process of quota allocation. This has led to a sharp increase in the price of cement.

Providing houses for employees by the employers is a solution that would have resolved housing deficit among public servants. This was noticeable in the 80's unlike now that it is expected of every individual to make a way for them. Ewumi (2013) has highlighted the discussion on the investment on houses made by employers for their employees at Satellite Town, Festac Town, Agbara Estate, Gbagada, Isolo. Most of these employees who are now retirees are landlord and landladies in the listed locations because of their employer's concern on welfare and housing provision.

\subsection{Study Area}

Ota, in Ado-Odo/Ota Local Government can be referred to as the "Local Government of Distinction" (http://ogun/gca.com/index.php). It is the most populous, industrialised Local Government in the state and second most industrialised area in the country. It came into existence in May 19, 1989 following the merging of Ota, part of the defunct Ifo/Ota Local Government with AdoOdo/Igbese Areas of the Yewa South Local Government. The Local Government is the second largest in Ogun State and its headquarters is at Ota. It is located within the tropical zone lying between 60 $470 \mathrm{~N}$ of the equator and $2033 \mathrm{oE}$ and $30180 \mathrm{E}$ of the Greenwich Meridian. It covers a land area of $1,263 \mathrm{sq}$ kilometres and it has a plain land of about 252.6 square kilometres with the bad terrain comprising of $16 \%$ riverine and $4 \%$ hilly regions.

The Local Government covers an area of 1460 square kilometres and share boundaries with Lagos State and Yewa in the South, Ifo Government Local Area in the West and Ipokia Local Government in the North East. From 2006 Census, Ado- Odo/Ota It has an estimated population of 527, 242 (Male 261, 523 and Female 265,710) with towns, villages and settlements. It is an economically developing local government that has one of the largest concentrations of industries; particularly the manufacturing and assembly plants abound in the area. These industries are located at Ota, Agbara and Sango- Ota, all under Ado-Odo/Ota Local Government. No doubt, the local government's proximity to Lagos (the commercial nerve centre of the country) coupled with its favourable topography and of course, the friendly nature of the Aworis has contributed to the concentration of industries in the area. It is also worthy to note that Ota in Ado/Odo Local Government Area, has a direct access road to the Republic of Benin (http://ogun/gca.com/index.php).

\subsection{METHODOLOGY}

In order to meet the main aim of the study, a survey was conducted among the civil servants. The study population comprise civil servants at the private tertiary institutions, workers at Mutual Benefit Insurance Company and High Court of Justice in Ota, Ogun State. They had worked for more than eleven (11) years and have acquired their own buildings. The survey questionnaires were distributed among 189 respondents whom are workers in these establishments and 174 were retrieved representing $92 \%$ of the population. Efforts were made to optimise the questionnaire before distribution. In addition to the questionnaires being administered, interviews were also conducted amongst them, which helped in making some relevant conclusions about the study.

A Post -Hoc Test is used for the analysis of this study. This is necessary because it is used in statistical hypothesis for the classification and investigation of the significance difference on factors responsible for constraints in accessibility to housing in the study area. Two items are said to have 
almost the same characteristics if the significance value is greater than 0.05 and the higher the value the closer the items in classification. Based on this fact, causative factors in the research tool can be grouped The mean value can be used in ranking. The causative factors are then arranged in ascending order.

Ezeigue (2 015) examined the causes of housing problems in Nigeria, using Awka as a case study. By using Post- Hoc Test, the researcher was of the view that poverty and the increase in population at the urban area are the main factors causing problem to housing in the study area. Similarly, Boanet and Chalermpong (2001) also examined the relationship between highways and urban development by using this analysis. These researchers were of the view that if highways improve accessibility, the accessibility premium will be reflected in higher land prices. Sim (2001) carried out a study on the effect of public perception on property values in close proximity to electricity distribution equipment. He concurred that there is a negative effect on value and desirability of property because of the perception of the public on risk associated with electricity distribution equipment. Meanwhile, before the classification of these factors, One-way analysis of variance was used to determine the significant causes of housing constraints among the target population.

\subsection{RESULTS AND DISCUSSION}

Table 1: Respondents and place of work

\begin{tabular}{|l|l|l|l|}
\hline S/N & Options & Respondents & Percentage (\%) \\
\hline 1. & Bells University of Tech. & 54 & 31.00 \\
\hline 2. & Covenant University & 29 & 16.70 \\
\hline 3. & All-over Polytechnic & 11 & 6.32 \\
\hline 4. & Ogun state general Hospital & 43 & 24.71 \\
\hline 5. & $\begin{array}{l}\text { Mutual benefit Insurance } \\
\text { company }\end{array}$ & 08 & 4.60 \\
\hline 6. & High Court & 29 & 16.67 \\
\hline & Total & $\mathbf{1 7 4}$ & $\mathbf{1 0 0}$ \\
\hline
\end{tabular}

Source: Field survey, 2017.

Table 1 represents the distribution of public servants in the various establishments in the study area. Bells University of Technology has the highest representation of population (31.0\%), followed by Ogun State General Hospital having a representation of (24.71\%) and Mutual Benefit Insurance has the least (4.6\%).

Table 2: Length of Service of Respondent in the various Institutions

\begin{tabular}{|l|c|c|c|}
\hline & Options & Respondent & Percentage (\%) \\
\hline Bellstech University & $<5$ years & 09 & 16.70 \\
\cline { 2 - 4 } & $6-10$ years & 31 & 57.40 \\
\cline { 2 - 4 } & 11 yrs above & 14 & 25.90 \\
\hline Covenant University & $<5 \mathrm{yrs}$ & 02 & 6.90 \\
\cline { 2 - 4 } & $6-10 \mathrm{yrs}$ & 17 & 58.60 \\
\cline { 2 - 4 } & 11 yrs above & 10 & 34.5 \\
\hline All-over polytechnic & $<5$ yrs & 02 & 18.20 \\
\cline { 2 - 4 } & $6-10 \mathrm{yrs}$ & 08 & 72.70 \\
\cline { 2 - 4 } & 11 yrs above & 01 & 9.10 \\
\hline
\end{tabular}




\begin{tabular}{|l|c|c|c|}
\hline $\begin{array}{l}\text { Ogun state general } \\
\text { hospital }\end{array}$ & $<5$ yrs & 03 & 6.90 \\
\cline { 2 - 4 } & $6-10 \mathrm{yrs}$ & 14 & 32.60 \\
\cline { 2 - 4 } & 11 yrs above & 26 & 60.50 \\
\hline \multirow{2}{*}{$\begin{array}{l}\text { Mutual benefit } \\
\text { Insurance }\end{array}$} & $<5$ yrs & 01 & 12.50 \\
\cline { 2 - 4 } & $6-10 \mathrm{yrs}$ & 05 & 62.50 \\
\cline { 2 - 4 } & 11 yrs above & 02 & 25.00 \\
\hline \multirow{3}{*}{ High court } & $<5$ yrs & 04 & 13.80 \\
\cline { 2 - 4 } & $6-10 \mathrm{yrs}$ & 10 & 34.48 \\
\cline { 2 - 4 } & 11 yrs above & 15 & 51.72 \\
\hline Total & & & $100 \%$ \\
\hline
\end{tabular}

Source: Field survey, 2017.

The numbers of staff, who have worked for the period of 6-10 years in the entire establishments, are more with $57.40 \%, 58.60 \%, 72.70 \%$ and $62.50 \%$ respectively. With the length of service, it is expected that they will have access to financial/monetary opportunities available in their place of work and at the same time the application for finance in the financial institutions would assisted them in property investment and development. The summary of the length of service is shown in Table 2.

Table 3: Staff with owned property (developed property)

\begin{tabular}{|c|c|c|}
\hline Options & Respondents & Percentage \% \\
\hline Bells University & 16 & 17.20 \\
\hline Covenant University & 20 & 21.50 \\
\hline All-Over Polytechnic & 04 & 4.30 \\
\hline $\begin{array}{c}\text { Ogun State General Hospital } \\
\text { Mutual benefit Insurance } \\
\text { company }\end{array}$ & 33 & 35.48 \\
\hline Ogun state high court & 03 & 3.22 \\
\hline TOTAL & $\mathbf{9 3}$ & $\mathbf{1 0 0 \%}$ \\
\hline
\end{tabular}

Source: Field survey, 2017.

Table 3 indicates that $35.48 \%$ of the respondents in the Ogun State General Hospital have properties that are developed, and this is followed by $21.50 \%$ of the staff of Covenant University and Ogun State High Court having a representation of $18.27 \%$. There is the possibility of an internal arrangement in their organisation for their staff as regards to access to fund which these workers have utilised. 
Table 4: Staff with owned property (undeveloped property)

\begin{tabular}{|c|c|c|}
\hline Options & Respondents & Percentage \% \\
\hline Bells University & 38 & 46.91 \\
\hline Covenant University & 09 & 11.11 \\
\hline All-Over Polytechnic & 07 & 8.64 \\
\hline $\begin{array}{c}\text { Ogun State General Hospital } \\
\text { Mutual benefit Insurance } \\
\text { company }\end{array}$ & 10 & 12.35 \\
\hline $\begin{array}{c}\text { Ogun state high court } \\
\text { TOTAL }\end{array}$ & 05 & 6.17 \\
\hline
\end{tabular}

Source: Field survey, 2017.

It can be depicted above that many of the staff have undeveloped plots among the respondents at Bells University while Mutual Benefit Insurance staff represent $6.17 \%$ and All-over polytechnic staff represent $8.64 \%$. There is the possibility of non-arrangement of internal sourced finance which could have assisted these workers compared to other organisations that have more workers with developed property. The workers in Bells University and Mutual Benefit Insurance are likely not financially capable to develop them. Despite their length of service in these organisations, it may be that access to funds for property development is not available.

Table 5: Nature of Property Owned

\begin{tabular}{|c|c|c|c|c|}
\hline Options & $\begin{array}{c}\text { Fully- } \\
\text { completed }\end{array}$ & $\begin{array}{c}\text { Not fully completed } \\
\text { (70\% stage of } \\
\text { completion: foundation, } \\
\text { wall, roofing, flooring, } \\
\text { doors/windows and } \\
\text { internal services.) }\end{array}$ & $\begin{array}{l}\text { Not fully completed } \\
(60 \% \text { stage of } \\
\text { completion: } \\
\text { foundation, wall, } \\
\text { roofing, flooring, } \\
\text { doors/windows) }\end{array}$ & $\begin{array}{l}\text { Not fully completed } \\
(55 \% \text { stage of } \\
\text { completion: foundation, } \\
\text { block wall, roofing, } \\
\text { flooring, window/doors } \\
\text { not fully installed) }\end{array}$ \\
\hline Bellstech & $02(12.5 \%)$ & $05(31.25 \%)$ & $03(18.75 \%)$ & $06(37.5 \%)$ \\
\hline Covenant Uni. & $07(35.0 \%)$ & $06(30.00 \%)$ & $06(30.00 \%)$ & $01(5.00 \%)$ \\
\hline All- over poly. & - & $01(25.00 \%)$ & $01(25.00 \%)$ & $02(50.00 \%)$ \\
\hline $\begin{array}{c}\text { Ogun state } \\
\text { general } \\
\text { hospital }\end{array}$ & $6(18.19 \%)$ & $11(33.33 \%)$ & $07(21.21 \%)$ & $09(27.27 \%)$ \\
\hline $\begin{array}{l}\text { Mutual benefit } \\
\text { insurance }\end{array}$ & $02(25.00 \%)$ & $02(25.00 \%)$ & $03(37.50 \%)$ & $01(12.5 \%)$ \\
\hline High court & $4(23.52 \%)$ & - & $08(47.06 \%)$ & $05(29.41 \%)$ \\
\hline Total & 21 & 25 & 28 & 24 \\
\hline
\end{tabular}

Source: Field survey, 2017. 
It is evident from Table 4 that most of the developed properties are not fully finished. One would notice in the study area that the presence of partly completed buildings are conspicuous. Many a times property owners move into their property with the intention of finishing it up gradually.

Table 6: Constraints of Property Ownership amongst Workers.

Univariate Analysis of Variance

\begin{tabular}{|l|c|c|}
\hline \multirow{3}{*}{ Between-Subjects Factors } \\
\hline \multirow{4}{*}{ Options } & Value Label & N \\
\hline \multirow{4}{*}{ Causes } & Bells University & 5 \\
\cline { 2 - 3 } & Covenant University & 5 \\
\cline { 2 - 3 } & All- over Polytechnic & 5 \\
\cline { 2 - 3 } & Mutual Benefit Insurance & 5 \\
\cline { 2 - 3 } & Ogun state general Hospital & 5 \\
\cline { 2 - 3 } & High Court & $5 \mathrm{z}$ \\
\hline & Finance & 6 \\
\cline { 2 - 3 } & Inst Imp & 6 \\
\cline { 2 - 3 } & Family Size & 6 \\
\cline { 2 - 3 } & Building Mater & 6 \\
\cline { 2 - 3 } & Construction & \\
\hline
\end{tabular}

Table 6 above shows the options (i.e. the organisations to be researched on) and the likely causes of housing constraints amongst the workers. These are titled as options and causes.

Table 7: Tests of Between-Subjects Effects

\begin{tabular}{|c|c|c|c|c|c|}
\hline \multicolumn{6}{|c|}{$\begin{array}{c}\text { Tests of Between-Subjects Effects } \\
\end{array}$} \\
\hline \multicolumn{3}{|c|}{ Dependent Variable: response } & \multirow[b]{2}{*}{$\begin{array}{l}\text { Mean } \\
\text { Square }\end{array}$} & \multirow[b]{2}{*}{$\mathrm{F}$} & \multirow[b]{2}{*}{ Sig. } \\
\hline Source & $\begin{array}{c}\text { Type III Sum } \\
\text { of Squares }\end{array}$ & Df & & & \\
\hline Model & $2409.867^{\mathrm{a}}$ & 10 & 240.987 & 19.116 & 0.000 \\
\hline Institute & 317.200 & 5 & 63.440 & 5.032 & .004 \\
\hline Causes & 1083.467 & 4 & 270.867 & 21.486 & .000 \\
\hline Error & 252.133 & 20 & 12.607 & & \\
\hline Total & 2662.000 & 30 & & & \\
\hline a. RS & $\mathrm{ed}=.905(\mathrm{~A}$ & $\overline{R s}$ & $=.858)$ & & \\
\hline
\end{tabular}




\section{Post Hoc Tests}

\section{Homogeneous Subsets}

\section{Response \\ Duncan}

\begin{tabular}{|c|c|c|c|}
\hline \multirow{2}{*}{ Options } & \multirow{2}{*}{ N } & \multicolumn{2}{|c|}{ Subset } \\
\cline { 3 - 4 } & & $\mathbf{1}$ & $\mathbf{2}$ \\
\hline Mutual Benefit insurance & 5 & 1.60 & \\
\hline All over polytechnic & 5 & 2.20 & 5.80 \\
\hline Covenant university & 5 & 5.80 & 5.80 \\
\hline High Court & 5 & 5.80 & 8.60 \\
\hline Ogun Hospital & 5 & & 10.80 \\
\hline Bells university & 5 & & .053 \\
\hline Sig. & & .100 & \\
\hline
\end{tabular}

\section{Generated from statistical analysis of author's fieldwork data.}

Means for group's homogeneous subsets are displayed. Based on observed means.

The error term is Mean Square (Error) $=12.607$.

\section{Response}

Duncan

\begin{tabular}{|c|c|c|c|}
\hline \multirow{2}{*}{ Causes } & \multicolumn{3}{|c|}{ Subset } \\
\cline { 2 - 4 } & $\mathbf{1}$ & $\mathbf{2}$ & $\mathbf{3}$ \\
\hline Construction process & .50 & & \\
\hline Family Size & 1.17 & & \\
\hline Building Materials & 2.83 & & 16.67 \\
\hline Institutional impediment & & 7.83 & 1.000 \\
\hline Finance & & & \\
\hline Sig. & .295 & 1.000 & \\
\hline
\end{tabular}

\section{Generated from statistical analysis of author's fieldwork data.}

Means for groups in homogeneous subsets are displayed. Based on observed means. The error term is Mean Square (Error) = 12.607.

From the result of the Post-Hoc (as shown above), there is 5\% significance difference and since this is significant, a pair-wise multiple comparison of means was conducted. The result shows that Finance and Institutional Impediment are significantly different from others. With the capital intensive nature of property, finance is very crucial in project development which has been highly rated as a major constraint by the workers. An institutional impediment is another major constraint to housing accessibility as indicated by the public servants in the study area. With the so-called property owners, they got their property through difficult means for housing to be made available to them. 
Table 8: Source of finance for property investment

\begin{tabular}{|c|c|c|c|c|c|}
\hline Options & $\begin{array}{c}\text { Equity } \\
\text { Capital }\end{array}$ & $\begin{array}{c}\text { Micro } \\
\text { finance } \\
\text { Bank }\end{array}$ & $\begin{array}{c}\text { Co-operative } \\
\text { Society }\end{array}$ & PMI's & $\begin{array}{c}\text { Loan from } \\
\text { Organization }\end{array}$ \\
\hline Bellstech Uni & $26(48.14 \%)$ & - & $21(38.90 \%)$ & - & $07(12.96 \%)$ \\
\hline Covenant Uni & $07(24.14 \%)$ & $17(58.62 \%)$ & $04(13.79 \%)$ & - & $01(3.45 \%)$ \\
\hline $\begin{array}{c}\text { All-over poly } \\
\text { Ogun state general } \\
\text { hospital }\end{array}$ & $14(32.56 \%)$ & - & $02(18.18 \%)$ & - & $02(18.18 \%)$ \\
\hline $\begin{array}{c}\text { Mutual benefit } \\
\text { insurance }\end{array}$ & $06(75.00 \%)$ & - & $02(25.00 \%)$ & - & $03(6.97 \%)$ \\
\hline $\begin{array}{c}\text { High court } \\
\text { (17.64\%) }\end{array}$ & $17(58.62 \%)$ & $02(6.90 \%)$ & $10(34.48 \%)$ & - & - \\
\hline
\end{tabular}

Source: Field survey, 2017

Table 8 shows that most property owners acquire their property through equity capital. None of them referred to the Primary Mortgage Institution as a means of their finance for housing. Only few establishments make funds available to staff as a form of loan that will be repaid.

\subsection{Discussions of Findings}

Having carried out various analyses of data collected from the respondents in the study area, the findings from the analysis revealed that finance and institutional impediments are the major factors responsible for housing constraints amongst public servants in Ota. Even with the so-called property owners, getting the fund to acquire their property was accessible through their own personal savings (equity capital). This did not give most of them the opportunity to fully complete the property to their own taste.

Institutional impediment is another factor in the sense that government policy in acquiring land and perfecting of land titles involve a long bureaucratic process that discourages one to develop houses. One might relate this to the persistence occurrence of land grabbing in the study area since there is no perfect titles papers to back up their ownership.

Ota is a fast growing city and this can be attributed to the number of industries as well as e existence the establishment of private tertiary institutions in the area. The presence of these institutions will in turn foster property development as well. From the findings shown in Table 5, it can be depicted that though the properties are developed, they are not fully completed. This is to highlight that these property owners accommodate the developed properties and gradually complete the building with time for the obvious reason of financial constraint. Likewise, Table 8 shows that the commonest and easiest way to raise fund amongst the respondents is through equity capital. The effort of government in the provision of housing or through the primary mortgage is not sufficient enough. 


\subsection{CONCLUSION AND RECOMMENDATIONS}

From the findings, it can be concluded that there are several factors that posed as constraints to housing among the public servants at the study area in Ota, Ogun State, Nigeria. The following recommendations are suggested as measures to improve urban infrastructures so that more urban cities can be created in Nigeria. Firstly, the Government should make housing as a priority to be pursued. The administrative culture of the Primary Mortgage Institution should be improved in such a manner that loan is accessible to low- income earners. Secondly, more affordable government housing units should be built. Most of the private estates are not affordable to all. Thirdly, the costs of building materials are on the high side. Government should subsidise the prices of building materials. This will aid the provision of houses to Nigerians. The government should also be involved in public-private partnership in housing delivery. It will quicken housing delivery system in the country. Lastly, land regularisation and registration system should also be made lot easier and have less of bureaucratic process. This will improve the number of people having title document for their property which would then lead to an improvement in property development and investment.

\subsection{REFERENCES}

1. Abiodun, J.O (1985). "The provision of housing and Urban Environmental Problems in Nigeria". Urban and Regional Planning problems in Nigeria Ed, University of Ife Press Ltd.174-179.

2. Alebiosu. A (2009). “ Nexus between Effective Land Management and Housing delivery in Lagos". International Journal of Environment and Urbanisation, Vol 23(1) 285-303.

3. Aluko B.T (2012). "Towards a Sustainable Housing Finance in Nigeria: The Challenges of Developing Adequate Housing Stock and a Road Map". Housing Finance International Summer.2012.

4. Boarnet and Chalermpong, S. (2001). New highways, house prices and urban development: a case study of toll roads in orange country CA. Fannie Mae Foundation.

5. Chris O. and Owar, M. "Mortgage Financing and Housing Development in Nigeria". International Journal of Research Granthalayah. VOL.5, May, 2017.

6. Ezeigue L (2015). " Land rights and secure tenure as the basis for economic empowerment and housing delivery". Paper presented at the stakeholders forum on land reform organised by the Federal Ministry of Environment ,Housing and Urban Development, Abuja, 6-7 November.

7. Lewin A.C (1981). Housing Cooperative in Developing Countries. John Wiley and Sons. New York 1981.

8. Olotuah, A.O (2015). "Sustainable Housing Provision for the Urban Poor: A review of Public Sector Intervention in Nigeria". The Built and Human Environmental Review, Vol. 2, 2009.

9. Olotuah, A.O (2000). "The Challenge of Housing in Nigeria". Effective housing in 21st century in Nigeria. Environmental Forum Federal University of Technology, Akure, Nigeria, $16-21$.

10. Olotuah A.O (2006). "Sustainable Low-Cost Housing Provision in Nigeria, A bottom up Participatory Approach". In Boyd, D (ed) proceeds of 22nd Annual ARCOM Conference, 4-6. Omirin, M (2007). "The Role of Primary Mortgage Institutions in Housing Delivery". Housing Finance International, 21(5), 52-56. 
11. Iyaiya, M (2012). "Microfinance and Mortgage Financing in Nigeria: A Rural Experience". International Journal of Economics and Management Sciences, 1(10), 39-44.

12. Nubi T.O (2010). "Towards a sustainable Housing Finance in Nigeria: The challenges of developing adequate housing stock and road maps". Housing Finance International Summer, 2010.

13. Nubi T.O and Ajoku (2011). "Nexus between effective Land Management and housing delivery in Lagos" International Institute for Environment and Development (IIED) Vol.23, 285-303.

14. Sim. D (2001). "Simplicity Versus Complexity in the evolution of Housing Finance System". In lea (ed) Secondary Mortgage Market: International Perspective Published by International Union of Housing Finance, Washington, US.

15. Ubom R.(2014). "Financing Affordable Housing in Nigeria" A paper presented at the International Workshop on Housing/Mortgage Finance in a Depressing Global Economy organised by Housing Advocacy at Victoria Docks London,

16. Udoka.F and Owar.O (2017). "Housing Finance in Nigeri: Need for Re-Engineering". International Union for Housing Finance, Special Series.

17. Warnock, V.C "Market and Housing Finance". Journal of Housing Economics, 17(3), 239251.

18. http://og un/gca.com/index.php. Cities on October, 2016. 